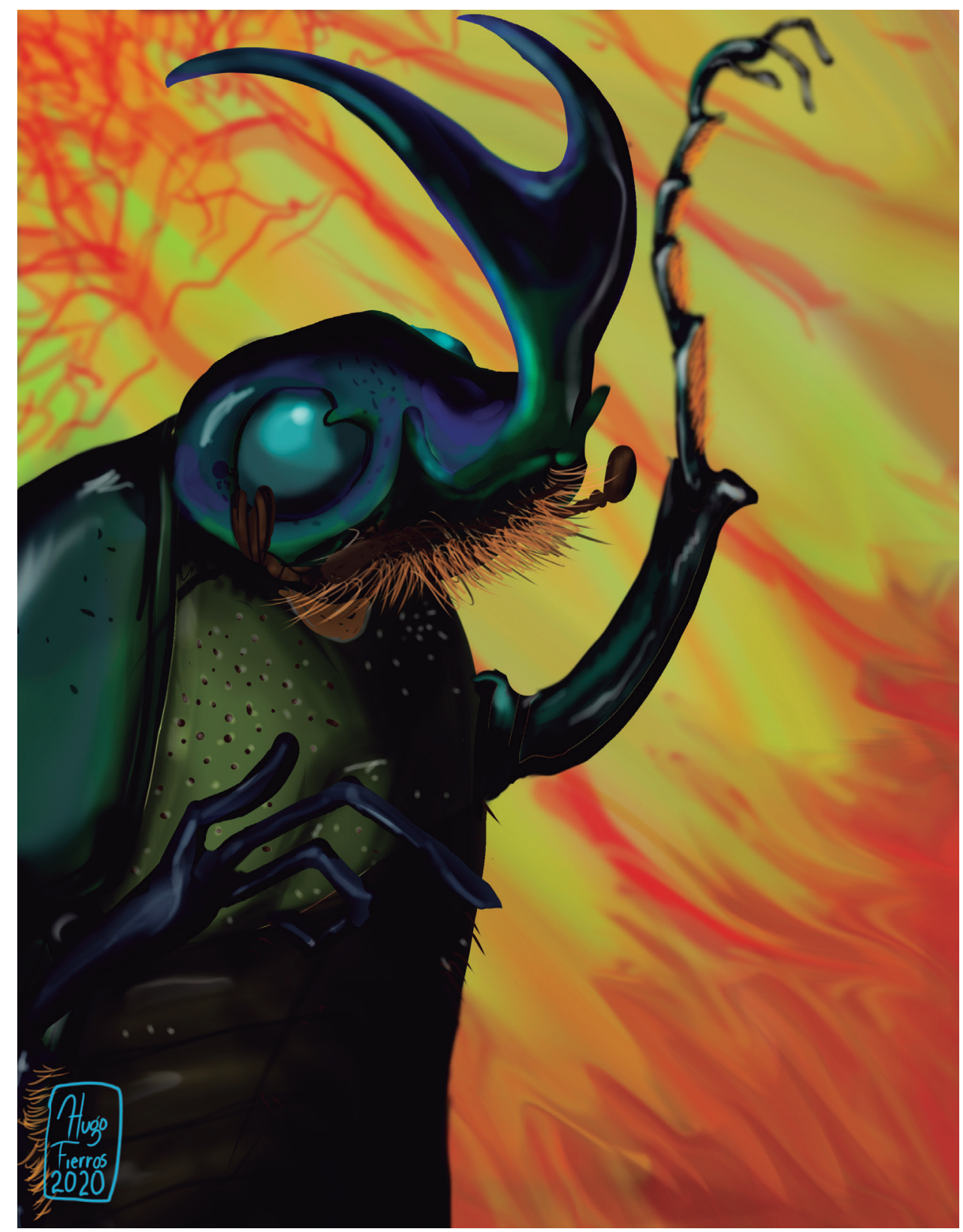

Dugesiana, Año 28, No. 1, (enero-junio, primer semestre de 2021), es una publicación semestral, editada por la Universidad de Guadalajara, a través del Centro de Estudios en Zoología, por el Centro Universitario de Ciencias Biológicas y Agropecuarias. Camino Ramón Padilla Sánchez \# 2100, Nextipac, Zapopan, Jalisco, Tel. 37771150 ext. 33218, http://148.202.248.171/dugesiana/index.php/DUG/index, glenusmx@gmail.com. Editor responsable: José Luis Navarrete-Heredia. Reserva de Derechos al Uso Exclusivo 04-2009-062310115100-203, ISSN: $2007-$ 9133, otorgados por el Instituto Nacional del Derecho de Autor. Responsable de la última actualización de este número: José Luis Navarrete-Heredia, Editor y Ana Laura González-Hernández, Asistente Editorial. Fecha de la última modificación 15 defebrero 2021, con un tiraje de un ejemplar.

Las opiniones expresadas por los autores no necesariamente reflejan la postura del editor de la publicación.

Queda estrictamente prohibida la reproducción total o parcial de los contenidos e imágenes de la publicación sin previa autorización de la Universidad de Guadalajara. 


\title{
A new species of Acerophagus Smith (Hymenoptera: Encyrtidae) from Vieques Island, Puerto Rico (USA), parasitoid of the mealybug Hypogeococcus sp. (Hemiptera: Pseudococcidae)
}

\section{Una nueva especie de Acerophagus Smith (Hymenoptera: Encyrtidae) de la Isla de Vieques, Puerto Rico (EE.UU.), parasitoide del piojo harinoso Hypogeococcus sp. (Hemiptera: Pseudococcidae)}

\author{
Serguei Vladimirovich Triapitsyn \\ Entomology Research Museum, Department of Entomology, University of California, Riverside, California, 92521, \\ USA, serguei.triapitsyn@ucr.edu, ORCID: https://orcid.org/0000-0002-5086-7847
}

\begin{abstract}
A new species of the genus Acerophagus Smith (Hymenoptera: Encyrtidae), A. belenaguirreae sp. n., is described from Vieques Island, Puerto Rico (USA) as a primary parasitoid of the mealybug Hypogeococcus sp. (Hemiptera: Pseudococcidae) on Achyranthes aspera var. aspera (Amaranthaceae) and Portulaca sp. (Portulacaceae). An identification key to females of Acerophagus species in the New World with dark cross bands on the gastral dorsum is provided. A lectotype is designated for Acerophagus californicus Rosen, which is illustrated.
\end{abstract}

Key words: Hymenoptera, Encyrtidae, Acerophagus, Vieques Island, parasitoid, mealybug, Hypogeococcus.

\section{RESUMEN}

Se describe una nueva especie del género Acerophagus Smith (Hymenoptera: Encyrtidae), A. belenaguirreae sp. n., de la Isla de Vieques, Puerto Rico (EE.UU.) como un parasitoide primario del piojo harinoso Hypogeococcus sp. (Hemiptera: Pseudococcidae) sobre Achyranthes aspera var. aspera (Amaranthaceae) y Portulaca sp. (Portulacaceae). Se proporciona una clave para la determinación de las especies de Acerophagus en el Nuevo Mundo con bandas cruzadas oscuras sobre el dorso abdominal. Se designa un lectotipo para Acerophagus californicus Rosen, el cual se ilustra.

Palabras clave: Hymenoptera, Encyrtidae, Acerophagus, Isla de Vieques, parasitoide, piojo harinoso, Hypogeococcus.

A new species of the genus Acerophagus Smith (Hymenoptera: Encyrtidae) is described herein from Vieques Island, Puerto Rico (USA) as a primary parasitoid of Hypogeococcus sp. (Hemiptera: Pseudococcidae) on chaffflower, Achyranthes aspera var. aspera (Amaranthaceae), and purslane, Portulaca sp. (Portulacaceae). It was discovered in the course of the recent survey for natural enemies of Hypogeococcus spp. mealybugs in Puerto Rico and the smaller, adjacent Caribbean islands (Triapitsyn et al. 2020). The mealybug host of this new Acerophagus sp. is a different species (Triapitsyn et al. 2020) from the Harrisia cactus mealybug, Hypogeococcus sp., which is an invasive pest devastating native cacti (Cactaceae) in Puerto Rico (Carrera-Martínez et al. 2015; Triapitsyn et al. 2018; Poveda-Martínez et al. 2019, 2020).

All the specimens had been initially preserved in $80 \%$ ethanol; later most of them were dried using a critical point dryer, point-mounted, and then one female was slidemounted in Canada balsam. Terms for morphological features in the description are mostly those of Gibson (1997). Measurements are given in micrometers $(\mu \mathrm{m})$ as length or length: width (for the wings). An abbreviation used is: $\mathrm{F}=$ antennal funicular segment. Type specimens of Acerophagus spp. are deposited in the Entomology Research Museum, University of California, Riverside,

California, USA (UCRC).

TAXONOMY

Acerophagus belenaguirreae Triapitsyn sp. $\mathrm{n}$.

(Figs 2-7)

http://zoobank.org/D33D33D7-4F84-4FBB-8F55A4F6C6CB17E8

Acerophagus sp. near nubilipennis Dozier: Triapitsyn et al. 2020: 371-373 (diagnosis, illustrations, comparison with A. nubilipennis Dozier and A. luteolus Rosen).

Type material. Holotype female [UCRC] on slide (Fig. 1) labeled: 1. "Puerto Rico: Vieques Island $18.096533^{\circ} \mathrm{N}$ $65.524992^{\circ} \mathrm{W} 24 \mathrm{~m}, 30$. iii.2019, S. V. Triapitsyn from Hypogeococcus sp. on Achirantes [sic] aspera var. aspera (Amaranthaceae), emerged 8.iv.2019, Y. Rodríguez Reyes, M. J. West Ortiz"; 2. "Mounted by V. V. Berezovskiy 2019 in Canada balsam"; 3. "Acerophagus o sp. near nubilipennis Dozier, luteolus Rosen Dry body L: 0.66 mm Det. by S. V. Triapitsyn 2019"; 4. [red] "Acerophagus belenaguirreae Triapitsyn HOLOTYPE †"; 5. [barcode database label] "UCRC UCRC_ENT 00542147". The holotype is dissected under 4 coverslips. Paratypes: same data as the holotype [2 females: one on point (UCRC_ENT 00542149) and the other in ethanol in a freezer, UCRC (UCRC_ENT 00542150)]; same data except on Portulaca 
sp. (Portulacaceae) [1 female on point, UCRC (UCRC_ ENT 00542148)].

Description. FEMALE (holotype). Color. Body and appendages (Figs 2,3) mostly yellow except for two distinct dark cross bands on gastral dorsum from cercal plates and one inconspicuous, incomplete lighter band anterior to them; flagellum of antenna partially dirty yellow (more so F5 and clava); eyes gray, ocelli pink; mesoscutum, axilla and scutellum darker yellow than the rest of body, tegula white, tip of ovipositor sheaths brown.

Sculpture. Head with reticulate sculpture; scape smooth; mesoscutum, axilla and scutellum with inconspicuous sculpture.

Pubescence. Mesosoma (except propodeum) dorsally with numerous dark setae.

Head (Fig. 4) about as wide as high. Frontovertex about $1.5 \times$ as long as wide and $0.35 \times$ head width. Toruli just below level of lower eye margin. Ocelli in an equilateral triangle; minimum distance between posterior ocelli (POL) $3.5 \times$ greater than that between posterior ocellus and eye margin (OOL); distance between posterior ocellus and occipital margin about $2 \times$ ocellar diameter. Maxillary palpus 3-segmented, labial palpus 2-segmented.

Antenna (Fig. 5) with radicle $3.0 \times$ as long as wide, rest of scape $4.1 \times$ as long as wide; pedicel $2.1 \times$ as long as wide, much longer than any funicular segment; funicular segments all wider than long, F2 the shortest and F5 the longest, only F5 with a multiporous plate sensillum; clava 3 -segmented, $1.9 \times$ as long as wide and about $1.4 \times$ as long as funicle.

Mesosoma (Fig. 6). Mesoscutum about $1.6 \times$ as wide as long; scutellum about as long as mesoscutum.

Wings (Fig. 7) not abbreviated, extending far beyond apex of gaster. Fore wing $2.6 \times$ as long as wide, with disc mostly hyaline except for a more or less triangular-shaped, conspicuous dark cloud behind stigmal vein; linea calva not interrupted, closed posteriorly by 2 lines of setae, filum spinosum with 3 setae; costal cell about $14 \times$ as long as wide, with setae on dorsal surface arranged in 1 incomplete row; marginal vein punctiform, postmarginal vein very short. Hind wing $4.8 \times$ as long as wide, with disc hyaline.

Legs. Mesotibial spur slightly shorter than mesobasitarsus.

Gaster (Fig. 6) longer than mesosoma. Ovipositor occupying about 0.6 length of gaster, exserted beyond its apex by about $0.2 \times$ total length of ovipositor, and $1.2 \times$ as long as mesotibia.

Measurements $(\mu \mathrm{m})$ of the holotype. Body (of the critical point-dried, point-mounted specimen prior to slidemounting) 660; mesosoma 314; metasoma 397; ovipositor 277. Antenna: radicle 18; rest of scape 124; pedicel 55; F1 12; F2 11; F3 14; F4 15; F5 21; clava 106. Fore wing 603: 233; longest marginal seta 24 . Hind wing 436: 91 ; longest marginal seta 36 .

Variation (dry-mounted, critical point-dried paratypes). Body length 690-760 $\mu \mathrm{m}$.
MALE. Unknown.

Diagnosis. In Rosen (1969), A. belenaguirreae keys to couplet 12 together with A. nubilipennis Dozier, originally described from Puerto Rico (Dozier 1926), and A. californicus Rosen from California, USA, both of which have two narrow, dark cross bands on the gastral dorsum from the cercal plates (Rosen 1969). Triapitsyn et al. (2020), who diagnosed A. nubilipennis and illustrated its holotype, mentioned the following morphological female features that separate A. belenaguirreae (as Acerophagus sp. near nubilipennis) from A. nubilipennis: the latter has very different proportions of the antennal segments, particularly of the scape, F4, F5 and clava being notably longer and relatively narrower, and its fore wing disc is more sparsely setose behind the submarginal vein anterior to linea calva (figs $4 \mathrm{c}$ and $4 \mathrm{~d}$, respectively, in Triapitsyn et al. 2020, p. 374) than in the former (Figs 5 and 7 , respectively). The female antenna and fore wing of $A$. belenaguirreae are more similar to those of $A$. luteolus Rosen from Trinidad and Tobago, known as a parasitoid of Ferrisia virgata (Cockerell) (Pseudococcidae) (Rosen 1969). However, in the latter the gaster is uniformly pale yellow (Rosen 1969). Acerophagus belenaguirreae is also similar to A. flavus Rosen from Jamaica, known as a parasitoid of an undetermined mealybug on an Acalypha sp. (Euphorbiaceae), but in the latter the fore wing is entirely hyaline and the female gaster is entirely about "cadmium yellow", without dark cross bands (Rosen 1969).

Females of $A$. californicus and A. belenaguirreae, which also have similar antennae and fore wings, differ in the following: in the former, the antennal clava (Fig. 10) is relatively longer and narrower, $2.4-2.7 \times$ as long as wide, and dark cross bands on the gastral dorsum are relatively narrower and less conspicuous (Fig. 9) than in the latter species (Figs 2, 6), in which the antennal clava (Fig. 5) is relatively shorter and wider, about $1.9 \times$ as long as wide.

Acerophagus belenaguirreae differs from A. papayae Noyes and Schauff, originally described from Mexico (Noyes and Schauff 2003), in having a relatively wider frontovertex, as indicated in the key below.

In Noyes (2010), who provided a diagnosis of Acerophagus, an account of its use in biocontrol, and a key to females of Costa Rican species, $A$. belenaguirreae keys to couplet 32 together with $A$. diux Noyes and A. charino Noyes, both of which lack the two distinct, dark cross bands on the gastral dorsum; also, their flagella of the female antennae are differently colored (the clavae are lighter colored).

Key to species of Acerophagus in the New World with at least two distinct dark cross bands on gastral dorsum from the cercal plates (females).

1. Fore wing disc more sparsely, less uniformly setose behind submarginal vein anterior to linea calva (Fig. 12) .................................. A. nubilipennis Dozier - Fore wing disc more densely, uniformly setose behind 
submarginal vein anterior to linea calva (Figs 7, 11) ........................................................ 2

2. Frontovertex about $2.0 \times$ as long as wide ............................. A papayae Noyes and Schauff

- Frontovertex at most $1.7 \times$ as long as wide 3

2. Antennal clava (Fig. 10) relatively longer and narrower, 2.4-2.7× as long as wide; dark cross bands on gastral dorsum relatively narrower and less conspicuous (Fig. 9) ......................................... A. californicus Rosen

- Antennal clava(Fig. 5) relatively shorter and wider, about $1.9 \times$ as long as wide; dark cross bands on gastral dorsum relatively wider and the two apical ones more conspicuous (Figs 2, 6) ................. A. belenaguirreae sp. $\mathrm{n}$.

Host. Hypogeococcus sp. (Pseudococcidae).

Etymology. This species is named after M. Belén Aguirre (FuEDEI, Hurlingham, Buenos Aires, Argentina) for her outstanding contributions to research on Hypogeococcus spp. mealybugs and their natural enemies and biological control.

Remarks. I examined part of the original syntype series of A. californicus which remained in UCRC, mounted on one of the two original slides in Hoyer's mounting medium (Rosen 1969). A lectotype is here designated to clear up confusion about status of the type specimens of $A$. californicus: while Rosen (1969, pp. 68-69) described this species from 26 female syntypes, Noyes (2019) indicated a "holotype" in UCRC, which was an invalid designation. Lectotype female [UCRC] on slide (Fig. 8) labeled: 1. "LOC 283 E. State St. El Centro, Calif. Date 22 Apr. 1966 HOST SPILOCOCCUS PRESSUS DET R. FLOCK 1966 ON OLEANDER R [faint, in pencil]"; 2. "CO-TYPES [in red ink] NAME Pseudaphycus [crossed out] Acerophagus californicus, n. sp. [in red ink] DET D. Rosen 1966 COLL DeB, Warner NO"; 3. [database barcode label] "UCRC ENT 023323"; 4. [a small white circle] "W. A. q". The following red (for the lectotype, on the upper side of the slide) and light blue (for the paralectotypes, on the underside of the slide) labels have been added to the original ones: "Acerophagus californicus Rosen, 1969 LECTOTYPE $q$ Des. by S. V. Triapitsyn 2020" and "Acerophagus californicus Rosen, 1969 PARALECTOTYPES 5 우 Des. by S. V. Triapitsyn 2020". The lectotype (Fig. 9), marked by an arrow in India ink on the coverslip, is in good condition, complete; it is the specimen in the middle of the top row of three females when viewed under a dissecting microscope (with their heads up). Paralectotypes: 5 females on the same slide. Specimens on this lectotype/paralectotype slide (Fig. 8) are too overcleared to be remounted in Canada balsam without having potential quality problems; at least for now, the slide remains to be in good original condition, with the water-soluble mounting medium holding well; the coverslip seems to be double-ringed, first with Zut ${ }^{\circledR}$ as the primary ringing compound (Triapitsyn and Kim 2008) and then with Canada balsam on top of that. The whereabouts of the remaining 20 paralectotypes are unknown although they could be in Steinhardt Museum of Natural History, Tel Aviv University, Tel Aviv, Israel (TAU); Rosen (1969, p. 69) indicated that some syntypes were in "the author's collection", which is now in TAU.

The only known host of $A$. californicus is Spilococcus pressus Ferris (Pseudococcidae) on oleander, Nerium oleander (Apocynaceae), from which the original syntype series was reared; the type locality of this species is El Centro, Imperial County, California, USA (Rosen 1969). On the lectotype slide, one of the labels provides a street address of the type locality (omitted in the original description), which corresponds to $32^{\circ} 47^{\prime} 29^{\prime \prime} \mathrm{N} 115^{\circ} 32^{\prime} 25^{\prime}$ W, $-13 \mathrm{~m}$; the original sample with mealybugs had been apparently collected by R. A. Flock, and the emerged parasitoids were then reared by P. DeBach and S. C. Warner. More recently, Zuparko (2015) mentioned several additional specimens from California that may be conspecific with A. californicus.

\section{ACKNOWLEDGMENTS}

I thank Christian W. Torres Santana (at that time with Arboreto Parque Doña Inés, Fundación Luis Muñoz Marín, San Juan, Puerto Rico) and Mike Barandiaran (Vieques National Wildlife Refuge, U.S. Fish \& Wildlife Service, Vieques Island, Puerto Rico) for help with applications for the required collecting permits, Yorelyz Rodríguez Reyes and Michael J. West Ortiz (Department of Biology, University of Puerto Rico - Río Piedras, San Juan, Puerto Rico) for help with rearing of the parasitoids, and also Vladimir V. Berezovskiy (UCRC) for mounting specimens. This research was supported by the Cooperative Agreement with the US Department of Agriculture, Agricultural Research Service to develop biological control for the Harrisia cactus mealybug (USDA-APHIS Farm Bill funding for Fiscal Year 2019).

\section{LITERATURE CITED}

Carrera-Martínez, R., L. Aponte-Díaz, J. Ruiz-Arocho and D.A. Jenkins. 2015. Symptomatology of infestation by Hypogeococcus pungens: contrasts between host species. Haseltonia, (21): 14-18.

Dozier, H.L. 1926. Some new Porto Rican scale parasites (Hymenoptera: Encyrtidae). Proceedings of the Entomological Society of Washington, 28 (5): 97-101.

Gibson, G.A.P. 1997. Chapter 2. Morphology and terminology. (pp. 16-44). In: Gibson, G.A.P., J.T. Huber and J.B. Woolley (Eds.). Annotated keys to the genera of Nearctic Chalcidoidea (Hymenoptera). NRC Research Press, Ottawa, Ontario, Canada.

Noyes, J.S. 2010. Encyrtidae of Costa Rica (Hymenoptera: Chalcidoidea), 3. Subfamily Encyrtinae: Encyrtini, Echthroplexiellini, Discodini, Oobiini and Ixodiphagini, parasitoids associated with bugs (Hemiptera), insect eggs (Hemiptera, Lepidoptera, Coleoptera, Neuroptera) and ticks (Acari). Memoirs of the American Entomological Institute, 84: 1-848. 
Noyes, J.S. 2019. Universal Chalcidoidea database. The Natural History Museum, London. http://www.nhm. ac.uk/chalcidoids. Accessed 8 June 2020.

Noyes, J.S. and M.E. Schauff. 2003. New Encyrtidae (Hymenoptera) from papaya mealybug (Paracoccus marginatus Williams and Granara de Willink) (Hemiptera: Sternorrhyncha: Pseudococcidae). Proceedings of the Entomological Society of Washington, 105 (1): 180-185.

Poveda-Martínez, D., M.B. Aguirre, G. Logarzo, L. Calderón, A. de la Colina, S. Hight, S. Triapitsyn, H. Diaz-Soltero and E. Hasson. 2019. Untangling the Hypogeococcus pungens species complex (Hemiptera: Pseudococcidae) for Argentina, Australia, and Puerto Rico based on host plant associations and genetic evidence. PLoS One, 14 (7): e0220366 (https://doi. org/10.1371/journal.pone.0220366).

Poveda-Martínez, D., M.B. Aguirre, G. Logarzo, S.D. Hight, S. Triapitsyn, H. Diaz-Soltero, M.D. Vitorino and E. Hasson. 2020. Species complex diversification by host plant use in an herbivorous insect: The source of Puerto Rican cactus mealybug pest and implications for biological control. Ecology and Evolution, 10 (19): 10463-10480. (https://doi.org/10.1002/ece3.6702).

Rosen, D. 1969. A systematic study of the genus

Recibido: 25 de junio 2020

Aceptado: 5 de septiembre 2020

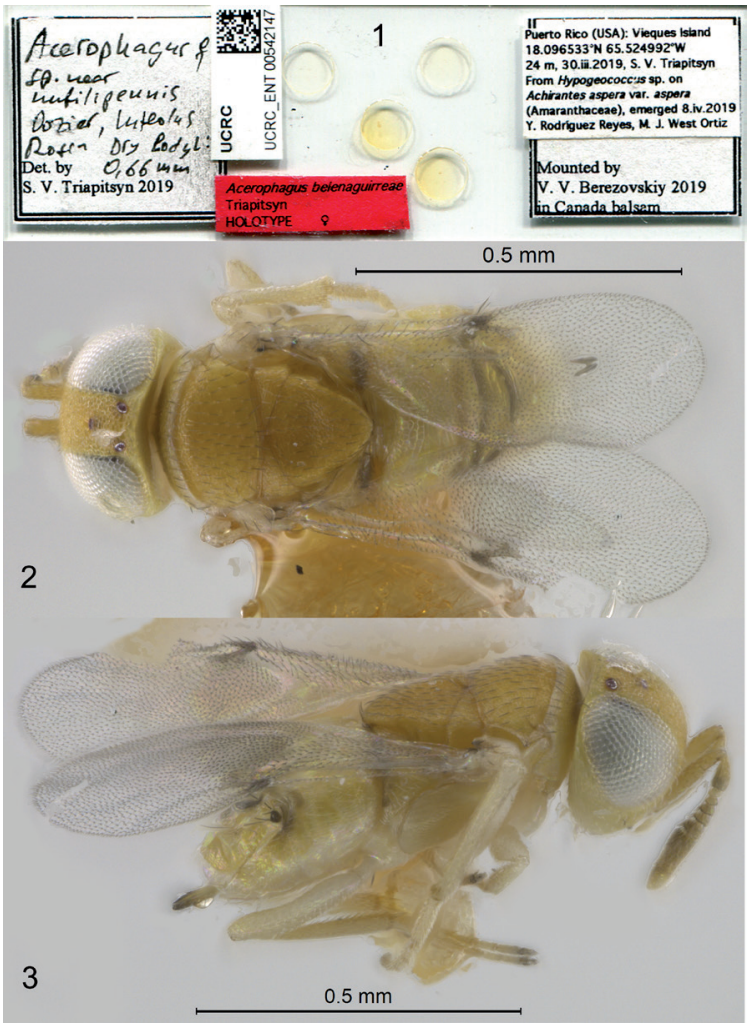

Figures 1-3. Acerophagus belenaguirreae (female): 1. Holotype slide. 2. Habitus of paratype in dorsal view. 3. Habitus of holotype in dorsolateral view.
Acerophagus E. Smith with descriptions of new species (Hymenoptera: Encyrtidae). Hilgardia, 40 (2): 41-72.

Triapitsyn, S.V., M.B. Aguirre, G.A. Logarzo, S.D. Hight, M.A. Ciomperlik, P.F. Rugman-Jones and J.C. Verle Rodrigues. 2018. Complex of primary and secondary parasitoids (Hymenoptera: Encyrtidae and Signiphoridae) of Hypogeoccoccus spp. mealybugs (Hemiptera: Pseudococcidae) in the New World. Florida Entomologist, 101 (3): 411-434.

Triapitsyn, S.V., S.D. Hight, G.A. Logarzo, M.B. Aguirre, J.C. Verle Rodrigues, V.A. Trjapitzin, Z. Rivera Ocasio, M.L. Rivera-Vázquez, M.J. West Ortiz and Y. Rodríguez Reyes. 2020. Natural enemies of the Harrisia cactus mealybug and other Hypogeococcus species (Hemiptera: Pseudococcidae) in Puerto Rico: Identification and taxonomic notes on primary and secondary parasitoids. Neotropical Entomology, 49 (3): 369-391.

Triapitsyn, S.V. and J.-W. Kim. 2008. An annotated catalog of the type material of Aphytis (Hymenoptera: Aphelinidae) in the Entomology Research Museum, University of California at Riverside. University of California Publications in Entomology, 129: i-viii + $1-124$.

Zuparko, R.L. 2015. Annotated checklist of California Encyrtidae (Hymenoptera). Zootaxa, 4017 (1): 1-126.

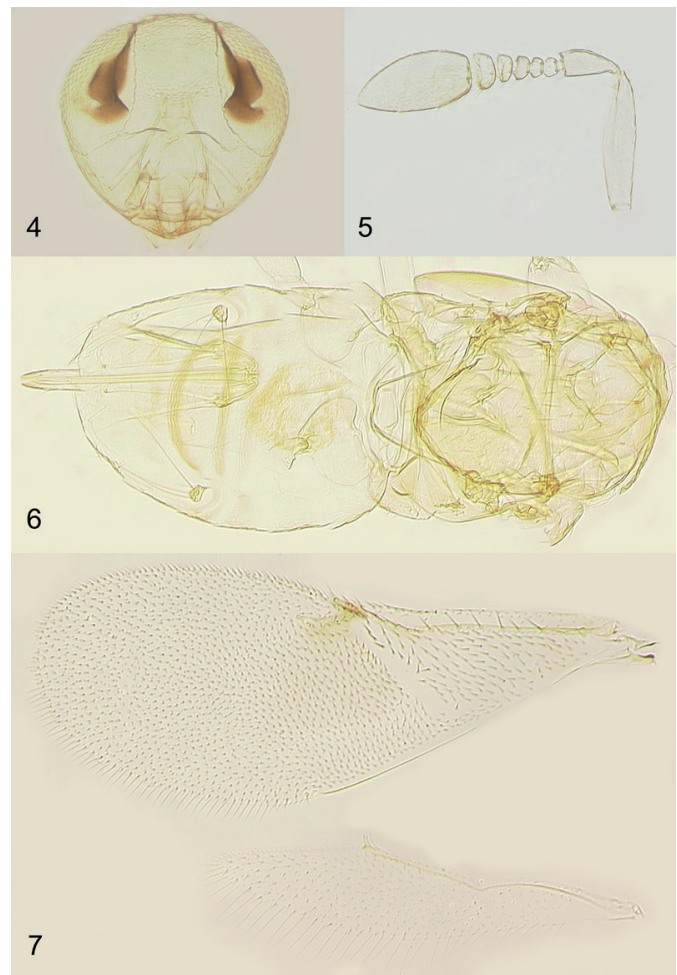

Figures 4-7. Acerophagus belenaguirreae (holotype female): 4. Head in frontal view. 5. Antenna. 6. Mesosoma and metasoma. 7. Fore and hind wings. 


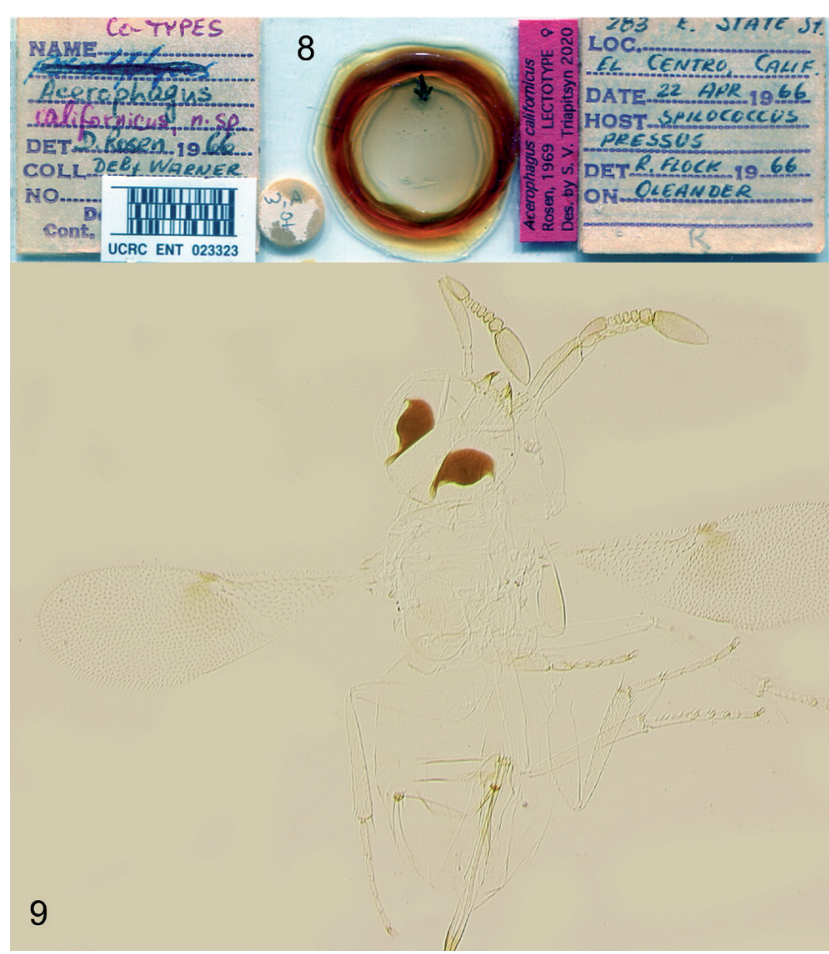

Figures 8-9. Acerophagus californicus (lectotype female): 8. Slide. 9. Habitus.

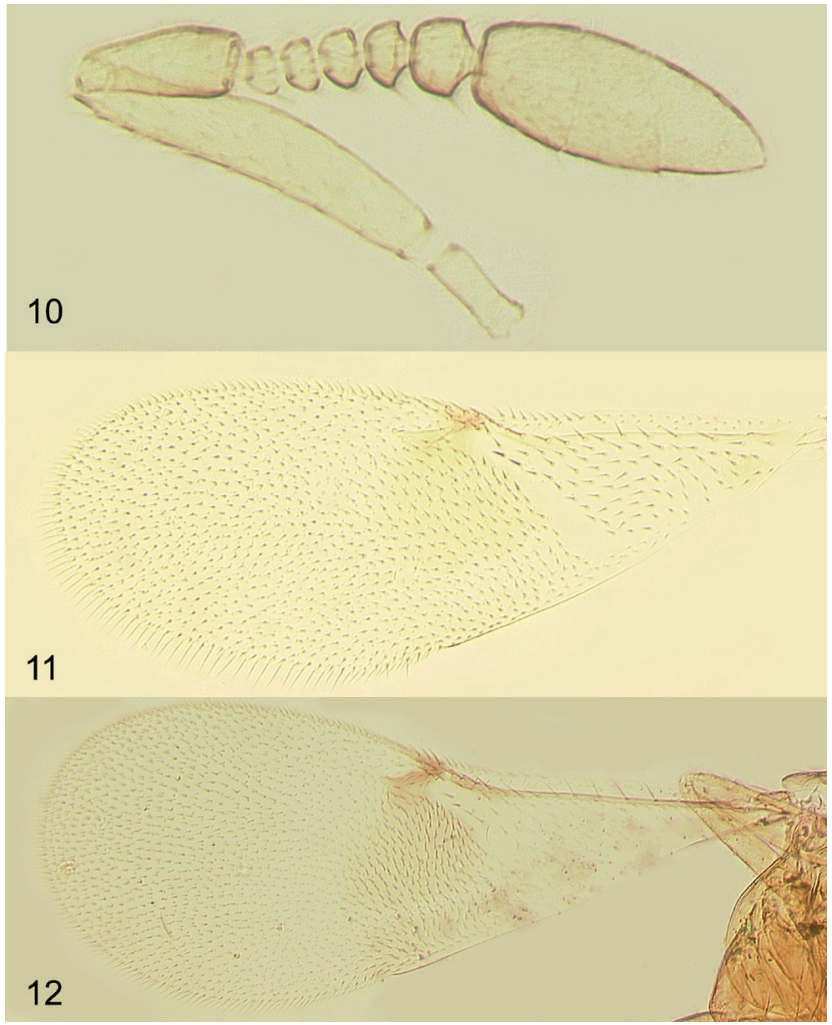

Figures 10-11. Acerophagus californicus (lectotype female): 10. Antenna. 11. Fore wing. Figure 12. Acerophagus nubilipennis (holotype female): fore wing. 